\title{
Haematological and serum biochemical parameters of West African Dwarf goats fed ensiled cassava leaves with or without molasses and caged layer waste \\ Oni*1 $^{1}$, A.O., Sowande ${ }^{3}$, O.S., Oduguwa ${ }^{4}$, B.O., Yusuf ${ }^{1}$, K.O., Arigbede ${ }^{2}$. O.M. and Onwuka ${ }^{1}$, C.F.I. \\ ${ }^{1}$ Department of Animal Nutrition; ${ }^{2}$ Department of Pasture and Range Management; ${ }^{3}$ Department of Animal Production and Health, College of Animal Science and Livestock Production, Federal University of Agriculture, PMB 2240, Abeokuta, Ogun State, Nigeria. \\ Abstract

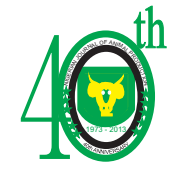

The study was conducted to evaluate the haematological and serum biochemical parameters of West African dwarf goats fed ensiled cassava leaves with molasses and caged layer waste. Eighteen West African dwarf goats were randomly assigned to three experimental diets consisting of cassava leaves ensiled alone (ECF), cassava leaves ensiled with 5\% molasses (ECFM) and cassava leaves ensiled with 5\% caged layer waste (ECFP) in a Completely Randomized Design. Results obtained showed that ensiling with molasses resulted in lower DM, CP, NDF, tannin and HCN levels. Crude protein intake was similar in ECF and ECFM but lower $(P<0.05)$ in ECFP ranging from 161.28 $172.71 \mathrm{~g} / \mathrm{d}$. The packed cell volume $(\mathrm{PCV})$, haemoglobin $(\mathrm{Hb})$ and lymphocyte concentrations were significantly $(P<0.05)$ highest in ECFP but similar with the values obtained for ECF. There were no significant $(P>0.05)$ differences in the red blood cells $(R B C)$, white blood cells $(W B C)$, neutrophil, basophil, eosinophil and monocytes contents in all the treatments. The highest significant $(P<0.05)$ value of $36.7 \mathrm{~g} / \mathrm{l}$ was obtained in ECFM and values of 29.4 and $24.0 \mathrm{~g} / \mathrm{l}$ in ECF and ECFP respectively for globulin. There was no significant $(P>0.05)$ difference in AST content in all the treatments. ALT value of $16.5 \mathrm{IU} / \mathrm{L}$ was significantly $(P<0.05)$ highest in ECF and different from the values of 12.0 $I U / L$ obtained in both ECFM and ECFP respectively. It is concluded that cassava leaves can be conveniently ensiled with 5\% of both molasses and caged layer waste without adverse effects on the haematological and biochemical status of WAD goats.

Keywords: Haematology, serum, molasses, caged layer waste

\section{Introduction}

Goats play a significant role in livelihoods of the rural populace in most developing countries. Apart from serving as a vital protein source, it also provides income for meeting urgent household needs (Peacock et al, 2005). In developing countries, goats play an important role in the economic life of the small holder farmers especially in converting low-cost inputs to high value products. Scarcity of forage during the dry season is a common problem limiting goat production in tropical areas (Nwaigwe, 2011). Excess forage produced during the wet season could be conserved in form of hay or silage and fed during the dry season.

Cassava (Manihot esculenta Crantz), a main cash crop, is among the most promising leaf protein source. Leaves from cassava contain compounds such as cyanide (HCN) and tannin which has potential negative effects on livestock performance and, for that reason, may limit the use of these fresh fodders to livestock. Many traditional African communities that consume cassava, which has been reported to contain high levels of cyanogenic glucosides, use fermentation as a means of detoxi cation of this food crop (Bradbury etal., 1991).

Haematological studies represent a useful process in the diagnosis of many diseases as well as investigation of the extent of damage to the blood (Onyeyili et al., 1991). This is relevant since blood constitutes a change in relation to the physiological conditions of the animals. Haematological studies are important because the blood is the major transport system of the body and 
evaluations of the haematological profile usually provide vital information on the body's response to injury of all forms, including feed toxicity (Ihedioha et al., 2004). Haematological constituents reflects the physiological responsiveness of the animal to its internal and external environments which include feed and feeding (Esonu etal., 2001) as well as drugs (Iheukwumere et al., 2007). Serum biochemical analysis is however, used to determine the level of heart attack, liver and kidney as well as to evaluate protein quality and amino acid requirements in animals(Harper et al., 1999). This study is designed to evaluate the haematological and serum biochemical parameters of West African Dwarf goats fed cassava leaves ensiled with molasses and caged layer waste.

\section{Materials and Methods}

The experiment was carried out at the Teaching and Research Farm, College of Animal Science and Livestock Production, University of Agriculture, Abeokuta. Cassava foliage (leaves + petiole) were evaluated in ensiling studies with or without additives. Molasses and caged layer waste were used as additives at 5\% (w/w) of fresh material. Cassava leaves of TMS 30572 variety of about 12 months old, were collected in the field immediately after root harvesting and allowed to wilt for a minimum of 12 hours in a well-ventilated shed. The leaves were thoroughly mixed with the additives in different silos, which constituted the different treatments as follows:

Treatment 1: cassava leaves alone Treatment 2: cassava leaves + molasses Treatment 3: cassava leaves + caged layer waste

Each treatment was replicated four times using a total of 12 plastic containers with capacity to contain $200 \mathrm{~kg}$ fresh materials each. The cassava leaves were chopped into pieces of $4-5 \mathrm{~cm}$ length and placed in two inserted polyethylene bags into the plastic containers. Molasses and caged layer waste were mixed with the chopped pieces at the time of filling and the materials were compacted by standing on the bags inside the containers. After filling, the tops of the bags were bound with rubber band and string and pressed by placing about $5 \mathrm{~kg}$ stones on top. The containers were stored in shade under a roof for a month to allow fermentation to occur.

\section{Experimental Animals, Management and Diets}

Eighteen West African Dwarf (WAD) male goats aged 12-15months with an average live weight of $7.2 \pm 1.2 \mathrm{~kg}$ were used for the experiment. The animals were housed intensively in well-ventilated individual pens $(1.2 \mathrm{~m} \times 0.90 \mathrm{~m})$, in an open-sided type of house with corrugated aluminium roofing sheet and a wooden floor, which had been disinfected with Izal solution before the arrival of the animals. The goats were vaccinated against Peste des petit de ruminant (PPR), given prophylactic treatments, which consisted of intramuscular application of oxytetracycline and Vitamin B complex at the dosage of $1 \mathrm{ml} / 10 \mathrm{~kg}$ body weight of the animal. They were dewormed with $1 \mathrm{ml} / 10$ $\mathrm{kg}$ body weight of albendazole ${ }^{\circledR}$ and treated against ectoparasites with $0.5 \mathrm{ml} / 10 \mathrm{~kg}$ body weight of Ivomec $^{\circledR}$. They were allowed an adaptation period of four weeks during which they were maintained on elephant grass and concentrate supplement with gradual withdrawal of the grass. Fresh water was supplied ad libitum. The experimental animals were divided into 6 animals per treatment and offered the different silage materials as indicated 
above. A basal diet of $1 \mathrm{~kg}$ Gmelina arborea foliage was offered daily to each goat. During the 84-days experimental period, quantities of feeds offered and refused were measured daily to compute feed intake on DM basis. Animals were fed at least 5\% of their body weight. Water and salt lick was given ad libitum.

\section{Collection of blood samples}

Blood samples (approximately $10 \mathrm{ml}$ ) were collected from each goat via jugular vein puncture using hypodermic syringes before feeding. Blood collection was done at the end of the experiment. Blood, $5 \mathrm{ml}$, was drawn into a heparinized tube to prevent coagulation while the remaining $5 \mathrm{ml}$ was left in the syringe to coagulate. Blood samples were then analysed for packed cell volume (PCV), $\mathrm{Hb}$, white blood cells (WBC), red blood cells (RBC), serum protein, serum glucose, serum albumin and globulin, serum creatinine, serum urea, mean corpuscular haemoglobin $(\mathrm{MCH})$, mean corpuscular haemoglobin concentration (MCHC), Aspartate aminotransferase (AST) and Alanine aminotransferase (ALT).

\section{Chemical analyses}

Aliquots of daily feed samples (concentrate and basal) were collected, oven-dried, ground and sieved through a 2-mm sieve and stored in airtight containers for proximate (AOAC 1995) and fibre (Van Soest et al. 1991) analyses. The packed cell volume was measured for each animal in fresh ethylene diamine tetra acetic acid (EDTA) anticoagulant samples within $24 \mathrm{~h}$ of collection using the micro-haematocrit method. Haemoglobin concentration was also measured in fresh EDTA anticoagulant samples using the Sahl's (acid haematin) method (Benjamin 1978). RBC was measured in fresh EDTA with the aid of
Neubaur counting chamber (haemocytometer). Blood smears were used for total thrombocyte, total WBC counts (Tavares-Dias et al. 2008), and WBC differential relative and absolute counts. Differential relative and absolute counts were classified as lymphocytes, neutrophils, eosinophils, basophils and monocytes. Plasma glucose was measured in fluoride oxalate anticoagulant blood samples using the enzymatic glucose oxidase method (Bauer et al. 1974). $\mathrm{MCH}$ and $\mathrm{MCHC}$ values were calculated from PCV, Hb and RBC values (Jain 1986). Total serum protein was measured in serum for individual animal using the biuret method. Aspartate aminotransferase (AST) and Alanine aminotransferase (ALT) were analysed spectrophotometrically by using commercially available diagnostic kits (Randox ${ }^{\circledR}$ Test Kits). Serum albumin and globulin were determined using bromocresol purple method of Varley et al. (1980). Serum creatinine was determined using the principle of Jaffe reaction as described by Bousnes and Taussky (1945).

\section{Statistical analyses}

All data were laid out as Completely Randomized design and analysed with One-way Analysis of Variance using SPSS (1999). Significant means were separated by Duncan's Multiple Range Test (Duncan, 1955).

\section{Results and Discussion}

The DM concentration of 252.4, 238.9 and $267.9 \mathrm{~g} / \mathrm{kg}$ DM obtained for ECF, ECFM and ECFP respectively (Table 1) were below the values of 329 and $363 \mathrm{~g} / \mathrm{kg} \mathrm{DM}$ obtained by Man and Wiktorsson (2001) for cassava tops silage with 0 and $6 \%$ molasses. Khang and Wiktorsson (2004) obtained value of $390.1 \mathrm{~g} / \mathrm{kg}$ DM for ensiled cassava tops while Eduardo et al. (2004) reported 
Blood parameters of WAD goats fed ensiled cassava leaves with or without molasses and caged layer waste

Table 1: Chemical Composition of the experimental diets (g/kg DM)

\begin{tabular}{llllll}
\hline \multirow{2}{*}{ Parameters $^{\mathbf{a}}$} & \multicolumn{5}{c}{ Treatments } \\
\cline { 2 - 6 } & ECF & ECFM & ECFP & FCF & Gmelina arborea \\
\hline Dry matter & 252.4 & 238.9 & 267.6 & 218.7 & 524.6 \\
Crude protein & 207.6 & 198.5 & 212.8 & 221.0 & 158.4 \\
Organic matter & 921.2 & 917.3 & 916.9 & 937.5 & 903.4 \\
Neutral detergent fibre & 561.4 & 547.9 & 591.2 & 622.5 & 447.0 \\
Acid detergent fibre & 413.7 & 372.7 & 391.8 & 414.0 & 159.5 \\
Acid detergent lignin & 26.1 & 24.5 & 27.3 & 25.1 & 103.5 \\
Tannin & 12.8 & 12.1 & 12.3 & 32.0 & 6.6 \\
HCN $(\mathrm{mg} / \mathrm{kg})$ & 95.8 & 84.7 & 89.3 & 112.3 & - \\
"Mean values $(\mathrm{n}=2)$ & & & & &
\end{tabular}

"Mean values $(\mathrm{n}=2)$

HCN: Hydrocyanic acid; ECF: Ensiled cassava leaves without additives; ECFM: Cassava leaves ensiled with molasses; ECFP: Cassava leaves ensiled with caged layer waste

FCF: Fresh cassava leaves

values of 25 and $27.7 \%$ for wilted and nonwilted aerial parts of cassava plants. Values obtained for CP are similar to those reported by several authors (Man and Wiktorsson, 2002 and Khang and Wiktorsson, 2004). The CP intake from silage (Table 2) was higher than values of $60.9 \mathrm{~g} / \mathrm{d}$ obtained by Bunyeth and Preston (2006) and values of between 41 to $55.5 \mathrm{~g} / \mathrm{d}$ reported by Seng Sokenya and Preston (2003). The high CP intake recorded in ECFM was due to the high DM intake of the animals on this treatment.

The haematological parameters of WAD goats fed ensiled cassava leaves indicated that PCV values of $17.5,21.5$ and $23.0 \%$ obtained fall within the range of $18-38 \%$ cited by Orheruata and Aikhuomobhogbe (2006) for WAD goats (Table 3). Animals on ECF and ECFM diets showed lower $\mathrm{Hb}$ concentration, which might be linked to depressed serum thyroxine function; however, whatever negative influence the toxicity of $\mathrm{HCN}$ and tannin could have

Table 2: Nutrient intake of West African Dwarf goats fed ensiled cassava leaves with or without additives

\begin{tabular}{|c|c|c|c|c|}
\hline \multirow[b]{2}{*}{ Parameters } & \multicolumn{4}{|c|}{ Treatment } \\
\hline & ECF & ECFII & ECFP & $\mathbf{P}$ \\
\hline \multicolumn{5}{|l|}{ DM intake $(g / d)$} \\
\hline Silage & $213.49 \pm 1.79^{\mathrm{b}}$ & $246.86 \pm 6.15^{\mathrm{a}}$ & $203.15 \pm 4.20^{\mathrm{b}}$ & 0.01 \\
\hline Gmelina & $279.72 \pm 11.97$ & $256.55 \pm 2.75$ & $255.16 \pm 4.05$ & 0.25 \\
\hline Total & $483.21 \pm 11.54^{\mathrm{ab}}$ & $503.42 \pm 8.49^{\mathrm{a}}$ & $458.43 \pm 7.87^{\mathrm{b}}$ & 0.04 \\
\hline CP intake & $172.71 \pm 3.47$ & $173.08 \pm 5.71$ & $161.28 \pm 4.83$ & 0.17 \\
\hline NDF intake & $347.10 \pm 5.77^{\mathrm{ab}}$ & $364.00 \pm 11.87^{\mathrm{a}}$ & $325.9 \pm 9.41^{\mathrm{b}}$ & 0.05 \\
\hline $\mathrm{HCN}$ intake $(\mathrm{mg} / \mathrm{kg})$ & $876.88 \pm 10.64^{\mathrm{a}}$ & $823.79 \pm 20.52^{\mathrm{ab}}$ & $786.13 \pm 13.19^{b}$ & 0.01 \\
\hline Tannin intake & $16.57 \pm 0.55$ & $15.90 \pm 0.31$ & $15.76 \pm 0.27$ & 0.82 \\
\hline \multicolumn{5}{|c|}{$\begin{array}{l}\text { abc: Means along the same row with different superscripts are significantly different } \\
(\mathrm{P}<0.05)\end{array}$} \\
\hline $\begin{array}{l}\text { ECF: } \quad \text { Ensiled cassava leaves without additives } \\
\text { ECFM: Ensiled cassava leaves with molasses }\end{array}$ & \multicolumn{4}{|c|}{ Ensiled cassava leaves without additives } \\
\hline ECFP: $\quad$ Ensile & \multicolumn{4}{|c|}{ Ensiled cassava leaves with caged layer waste } \\
\hline
\end{tabular}


Oni, Sowande., Oduguwa, Yusuf, Arigbede and Onwuka

Table 3: Haematological parameters of West African dwarf goats fed ensiled cassava leaves with or without additives

\begin{tabular}{|c|c|c|c|c|c|}
\hline \multirow[b]{2}{*}{ Parameters } & \multirow[b]{2}{*}{$\begin{array}{l}\text { Normal }^{\mathrm{c}} \\
\text { Values }\end{array}$} & \multicolumn{4}{|c|}{ Treatments } \\
\hline & & ECF & ECFM & ECFP & $\mathbf{P}$ \\
\hline $\begin{array}{l}\text { Packed cell } \\
\text { volume (\%) }\end{array}$ & $22-38$ & $21.5 \pm 1.44^{\text {ab }}$ & $17.5 \pm 0.29^{b}$ & $23.0 \pm 1.73^{\mathrm{a}}$ & 0.05 \\
\hline $\begin{array}{l}\text { Haemaglobin } \\
\text { concentration }(\mathrm{g} / \mathrm{dl})\end{array}$ & $8-12$ & $7.6 \pm 0.43^{\mathrm{ab}}$ & $6.1 \pm 0.35^{\mathrm{b}}$ & $8.0 \pm 0.58^{\mathrm{a}}$ & 0.05 \\
\hline $\begin{array}{l}\text { Red blood cells } \\
\left(\times 10^{12} / 1\right)\end{array}$ & $8-18$ & $10.3 \pm 0.66$ & $11.2 \pm 2.80$ & $14.5 \pm 3.75$ & 0.55 \\
\hline $\begin{array}{l}\text { White blood cells } \\
\left(\times 10^{9} / 1\right)\end{array}$ & $4-13$ & $7.8 \pm 0.14$ & $8.6 \pm 0.40$ & $7.4 \pm 0.26$ & 0.67 \\
\hline $\mathrm{MCH}(\mathrm{pg})$ & $5.2-8.0$ & $7.4 \pm 0.05$ & $7.3 \pm 0.34$ & $7.4 \pm 0.13$ & 0.90 \\
\hline $\mathrm{MCHC}(\%)$ & $30-36$ & $35.2 \pm 2.13$ & $34.9 \pm 2.41$ & $34.9 \pm 2.33$ & 0.96 \\
\hline Neutrophil (\%) & $30-48$ & $37.5 \pm 3.18$ & $52.5 \pm 4.33$ & $32.8 \pm 7.95$ & 0.10 \\
\hline Lymphocyte (\%) & $50-70$ & $57.5 \pm 1.44^{\mathrm{a}}$ & $46.5 \pm 3.75^{\mathrm{b}}$ & $59.0 \pm 3.46^{\mathrm{a}}$ & 0.05 \\
\hline Basophil (\%) & $0-2$ & $0.8 \pm 0.33$ & $0.0 \pm 0.00$ & $0.0 \pm 0.00$ & 0.07 \\
\hline Eosinophil (\%) & $3-8$ & $2.0 \pm 1.00$ & $0.0 \pm 0.00$ & $0.7 \pm 0.33$ & 0.14 \\
\hline Monocyte (\%) & $0-4$ & $3.0 \pm 0.58$ & $1.0 \pm 0.58$ & $1.0 \pm 0.58$ & 0.08 \\
\hline
\end{tabular}

ab: Means along the same row with different superscripts are significantly different $(\mathrm{P}<0.05)$

${ }^{\mathrm{c}}$ Normal values according to Fraser and Mays (1986); ECF: Ensiled cassava leaves alone ECFM: Ensiled cassava leaves with molasses; ECFP: Ensiled cassava leaves with poultry manure; MCH: Mean Corpuscular Haemoglobin; MCHC: Mean Corpuscular Haemoglobin Concentration

produced, the $\mathrm{Hb}$ levels of the animals was not drastic enough to alter the oxygen transportation within the animals physiological system (Oni et al. 2008, Oduguwa et al, 2013). A high neutrophil value was obtained in goats fed ECFM diet. The concentration of neutrophil was determined by the level of stress the animal was exposed to (Brij et al. 1977). The higher level of neutrophil was generated by livestock in a bid to fight against foreign bodies and this may also have been responsible for the higher values of WBC recorded in this treatment. From the result of the absolute leukocyte count, it could be observed that lower values were obtained in the lymphocyte for ECFM which indicates a less effective antibody production as reported by Frandson (2003) that, one of the major functions of lymphocyte is their response to antigen (foreign bodies) by forming antibodies that circulate in the blood or in the development of cellular immunity. A lower lymphocyte count recorded in this study for animals on ECFM is therefore, considered to be of immense clinical importance as reported by Ihedioha (2008) who stated that lymphocytes are responsible for immune-mediated defense of the body (cell-mediated and humoral immunity) and that low percentage of lymphocyte implies that the animals appears to be more susceptible to secondary and opportunistic infections.

The serum biochemical and enzyme parameters monitored were not significantly different $(\mathrm{P}>0.05)$ except 
globulin and ALT (Table 4). The high serum protein obtained in ECFM was indicative of good performance characteristics of the animals. Iyayi and Tewe (1998) reported a high, significant correlation between serum total protein and performance parameters in livestock. The low total protein obtained in ECFP implies that there is an alteration in protein metabolism of the animal since protein synthesis is related to the amount of protein available (Iyayi and Tewe, 1998) in the diet. The values reported for serum urea were within the value of $19.0 \mathrm{mg} / \mathrm{dl}$ reported by Taiwo and Ogunsanmi (2003). These values explain the availability of high quality protein and a proper functioning of the kidney.

The low levels of globulin obtained in this study were contrary to values reported by Esugbohungbe and Oduyemi (2002) and Ikhimioya and Imasuen (2007). However, this low level suggests that the effect of tannin in the diets may be interfering with protein metabolism in the animals. Higher globulin value was recorded in ECFM and a lower value than the normal range for ECFP. This is indicative of low immunity and poor resistance to disease in these animals as reported by Frandson (2003) that the gamma globulin fraction of the plasma protein is associated with immunity and resistance to disease. There was no significant $(\mathrm{P}>0.05)$ difference in AST but the values of 52.0, 46.5 and $41.0 \mathrm{IU} / \mathrm{L}$ obtained for ECF, ECFM and ECFP respectively, were below the normal values of 66-230 IU/L for WAD goats. However, the values reported here for ALT and AST were within the range reported by Daramola et al. (2005). The relatively close but low mean levels observed for AST in silages with additives could be an indication that the test diets did not differ in their influences or on enzyme secretion

Table 4: $\quad$ Serum biochemical and enzyme parameters of West African dwarf goats fed ensiled cassava leaves with or without additives

\begin{tabular}{|c|c|c|c|c|c|}
\hline \multirow[b]{2}{*}{ Parameters } & & \multicolumn{4}{|c|}{ Treatments } \\
\hline & $\begin{array}{l}\text { Normal }^{\mathrm{c}} \\
\text { Values }^{2}\end{array}$ & ECF & ECFM & ECFP & $\mathbf{P}$ \\
\hline Glucose (mg/dl) & $48.2-76$ & $56.5 \pm 6.64$ & $53.1 \pm 1.24$ & $62.0 \pm 1.15$ & 0.33 \\
\hline Total protein (g/l) & $61-74$ & $62.9 \pm 4.94$ & $68.6 \pm 1.67$ & $58.8 \pm 0.98$ & 0.15 \\
\hline Urea (mg/dl) & $12.6-25.8$ & $18.5 \pm 0.03$ & $19.7 \pm 1.53$ & $19.5 \pm 0.89$ & 0.69 \\
\hline Albumin (g/l) & $23.5-35.7$ & $33.5 \pm 0.03$ & $32.0 \pm 1.24$ & $34.9 \pm 1.24$ & 0.21 \\
\hline Globulin (g/l) & $27-44.3$ & $29.4 \pm 4.91^{\mathrm{ab}}$ & $36.7 \pm 2.92^{\mathrm{a}}$ & $24.0 \pm 2.22^{\mathrm{b}}$ & 0.01 \\
\hline Creatinine (g/l) & $0.7-1.5$ & $0.9 \pm 0.03$ & $0.9 \pm 0.06$ & $0.9 \pm 0.06$ & 0.73 \\
\hline AST (IU/L) & $66-230$ & $52.0 \pm 3.81$ & $46.5 \pm 4.23$ & $41.0 \pm 4.02$ & 0.63 \\
\hline ALT (IU/L) & $15.3-25.3$ & $16.5 \pm 0.87^{\mathrm{a}}$ & $12.0 \pm 1.15^{\mathrm{b}}$ & $12.0 \pm 0.56^{\mathrm{b}}$ & 0.01 \\
\hline $\begin{array}{l}\text { ab : Means along th } \\
\quad(\mathrm{P}<0.05) \\
{ }^{\mathrm{c}} \text { Normal values ac } \\
\text { AST: Aspartate an } \\
\text { alone; ECFM: Ens } \\
\text { manure }\end{array}$ & $\begin{array}{l}\text { same row wit } \\
\text { rding to Fras } \\
\text { hotransferase } \\
\text { ed cassava le }\end{array}$ & $\begin{array}{l}\text { ferent superscri } \\
\text { Id Mays (1986) } \\
\text { T: Alanine ami } \\
\text { with molasses; }\end{array}$ & are significantl & different & $\begin{array}{l}\text { eaves } \\
\text { ultry }\end{array}$ \\
\hline
\end{tabular}


mechanism.

\section{Conclusion}

It can be concluded from this study that both molasses and caged layer waste can be used to ensile cassava leaves without adverse effects on the haematological and serum biochemical parameters of West African dwarf goats.

\section{References}

A.O.A.C. 1995. Association of Official Analytical Chemists. Official Method of Analysis. $16^{\text {th }}$ Edition. Washington DC.

Oduguwa, B.O., Oni, A.O., Arigbede, O.M., Adesunbola, J.O. and Sudekum, K.H. 2013. Feeding potential of cassava (Manihot esculenta Crantz) peels ensiled with Leucaena leucocephala and Gliricidia sepium assessed with West African dwarfgoats. Tropical Animal Health and Production, 45:1363-1368

Bauer, T.D., Ackermann, P.G. and Toro, G. 1974. Methods in clinical chemistry. Clinical laboratory methods. The C.V. Mosley Company, Saint Louis, P. 946.

Benjamin, M.M. 1978. Outline of Veterinary Clinical Pathology, $2^{\text {nd }}$ Edition. Iowa State University Press, Iowa, U.S.A., 35-105

Bousnes, R. and Taussky, H.H. 1945. Colorimetric determination of creatinine by Jaffe 'reaction. Journal of Biochemistry, 158, 581-591.

Bradbury, J.H, Egan, S.V and Lynch, M.J. 1991. Analysis of cyanide in cassava using acid hydrolysis of cyanogenic glycosides. Journal of Science of Food and Agriculture, 55:277-290.

Brij, M.A., Horward, M.R. and Bhuran, V.V. 1977. Clinical, biochemical and haematological values in normal experimental animals. Masan
Publishing Co. USA.

Bunyeth, $H$ and Preston T. R. 2006. Growth performance and parasite infestation of goats given cassava leaf silage or sun-dried cassava leaves, as supplement to grazing in lowland and upland regions of Cambodia. Livestock Research and Rural Development, Volume 18, Article \#28. Retrieved A ugu s t 24,2007 from http://www.cipav.org.co//rrd18/2/buny /8028.htm

Cheeke, P. R. 1999. Applied Animal Nutrition. Feeds and Feeding, $2^{\text {nd }}$ Edition, Upper Saddle River, NJ: Prentice Hall, pp 185-186.

Daramola, J. O., Adeloye, A.A. Fatoba, T.A. and Soladoye, A.O. 2005. Haematological and biochemical parameters of West African dwarf goats. Livestock Research for Rural Development. Volume 17 Retrieved $\begin{array}{llll}\mathrm{f} & \mathrm{r} & \mathrm{o} & \mathrm{m}\end{array}$ http://www.cipva.org.co/lrrd/lrrd17/8/ dara17095.htm.

Duncan, D.B. 1955. Multiple Range and Multiple F. Tests. Biometrics, 11: 1-42.

Esonu, B. O., Emenalom, O. O., Udedibie, A. B. I., Herbert, U., Ekpor, C. F., Okoli, E. C., and I h e kwumere, F. C. 2001 . Performance and Chemistry of Weaners Pigs fed raw mucuna bean (Velvet bean) meal. Trop. Anim. Prod. Invest. 4:49-54.

Esugbohungbe, O. O. and Oduyemi, A.0. 2002. Comparisons of nutritional potentials of Terminalia catappa and Acalypha wilkesiana leaves as sole feed for goats. In: Increasing household protein consumption through improved livestock production, (eds. V.A. Aletor and G.E. Onibi). Proceedings of the $27^{\text {th }}$ Annual conference of the Nigerian Society of 
Animal Production held at Federal University of Technology, Akure, Nigeria, March 17-21, Pp. 205-208.

Frandson, R. D. 2003. Anatomy and Physiology of Farms Animals. $6^{\text {th }}$ Edition, Wiley- Blackwell, pp. 462.

Harper, A. E., Rodwell and Mayes, P. A. 1999. Review of light and breeding schedule on rabbit performance. Journal of Applied Rabbit Research, 5:33-37.

Ihedioha, J. T., Okafor, C. and Ihediola, T. E. 2004. The haematological profile of the Sprague Dawley out-bred albino rat in Nsukka. Animal Research International, 1:125-132.

Ihedioha, J. T., Okerie-Kanu, C. O. and Iwuogu, U. M. 2008. Leukocyte alterations associated with continual sub-acute blood loss. In: Animal Agriculture towards millennium development in Nigeria (eds. O.A. Adeyemi., A.M. Ogungbesan, A.O. Dada., O.O. Eniolorunda., H.A. Awojobi., D.B. Oke and J.A. Agunbiade). Proceedings of 33rd Annual Conference of Nigerian Society of Animal Production (NSAP) held at the College of Agricultural Sciences, Olabisi Onabanjo University, Yewa Campus, Ayetoro, Ogun State: 55-57.

Iheukwumere, F. C., Herbert, U., Iloeje, M. U. and Onyekwere, M. 2007. Physiological response of West African Dwarf does to progesterone injections: Haematology and serum biochemistry. In: Sustainability of the livestock industry in an oil economy (eds. E.A. Agiang., L.N. Agwunobi and O.O. Olawoyin). Proceedings of the $32^{\text {nd }}$ Annual Conference of the Nigerian Society for Animal Production held in University of Calabar, Cross River
State, Nigeria, March 18-21: 79-82.

Ikhimioya, I. and Imasuen, J.A. 2007. Blood profile of West African dwarf goats fed Panicum maximum supplemented with Afzelia Africana and Newbouldia laevis. Pakistan Journal of Nutrition, 6(1): 79-84.

Iyayi, E. A. and Tewe, O. O. 1998. Serum Total Protein, Urea, Creatinine levels as indices of cassava diet for pigs. Trop. Vet, 8:11-15.

Jain, N. C., 1986. Schalman's Veterinary Haematology, $4^{\text {th }}$ edition. Lea and Febiger, Philadelphia, P. A., USA, 208-224

Khang, D.N. and Wiktorsson, H. 2004. Effects of ensiled cassava tops on rumen environment parameters, thyroid gland hormones and liver enzymes of cows fed urea-treated fresh rice straw. Asian-Aust. J. Anim. Sci. 17 (7): 936-941.

Maldonado, R. A. P., Norton, B. W. and Kerven, G. L. 1995. Factors affecting in vitro formation of tannin-protein complexes. Journal of Science of Food and Agriculture, 69: 291-298.

Man, N. V. and Wiktorsson, H. 2001. Cassava tops ensiled with or without molasses as additive effects on quality, feed intake and digestibility by heifers. Asian-Australasia Journal of Animal Science, 14 (5): 624-630.

Man, N.V. and Wiktorsson, H. 2002. Effect of molasses on nutritional quality of cassava and gliricidia tops silage. Asian-Australasia Journal of Animal Science, 15 (9): 1294-1299.

McDonald, P., Edward, R.A. and Greenhalgh, J.F.D. 1988. Animal Nutrition, $4^{\text {th }}$ Edition, Longman, Edinburgh, UK.

Nwaigwe, C.O., Nwankpa C.A. and Nwaigwe, C.U. 2011. The effects of sawdust/poultry litter and Brachiaria 
ruziziensis silages on the performance of West Africa dwarf goats. Asian Journal of Biotechnology, 3: 581-587.

Oni, A.O., Onwuka, C.F.I., Oduguwa, O.O., Onifade, O.S. and Arigbede, O.M. 2008. Utilization of citrus based diets and Enterolobium cyclocarpum (JACQ GRISEB.) foliage by West African dwarf goats, Livestock Science, 117: $184-191$.

Onyeyili, P. A., Egwu, G. O., Jibike, G. I., Pepple, D. J. and Gbaegbulan, J. O. 1991. Seasonal variations in haematological indices in the greybreasted guinea fowls (Numida meleagris gallata, Pallas). Nigerian Journal of Animal Production, 18(2):108-111.

Orheruata, A. M. and Aikhuomobhogbe, P. U. 2006. Haematological and blood biochemical indices in West African dwarf goats vaccinated against Pestes des petit ruminants (PPR). African Journal of Biotechnology, 5(9): 743-748.

Peacock C., Devendra C., Ahuya C., Roets, M., Hossain, M. and Osafo, E. 2005. Goats. In: Owen,E.; Kitalyi, A.; Jayasuriya N.; Smith, T.; (eds), Livestock and Wealth Creation: Improving the husbandry of animals kept by resource-poor people in developing countries. Nottingham University Press, United Kingdom, pp. 361-385.

Tavares-Dias, M., Oliveira-Ju'nior, A., Marcon, J.L., 2008. Methodological limitations of counting total leukocytes and thrombocytes in reptiles (Amazon turtle, Podocnemis expansa): An analysis and discussion. Acta Amazonica, 38, 159-163.

Sokerya, S. and Preston, T. R. 2003. Effect of grass or cassava foliage on growth and nematode parasite infestation in goats fed low or high protein diets in confinement. Livestock Research for Development (15)8. $\mathrm{R}$ e $\mathrm{t} \mathrm{r}$ e $\mathrm{v}$ e d f r o m http://www.cipav.org.co/Lrrd15/8/ker y158.htm

SPSS 1999. Statistical package for social sciences. Procedures and facilities for release. McGraw-Hill Book Co. NY.

Taiwo, V.O. and Ogunsanmi, A.O. 2003. Haematology, plasma, whole blood and erythrocyte biochemical values of clinically healthy captive-reared grey duiker (Sylvicarpa grimmia) and West African dwarf sheep and goats in Ibadan, Nigeria. Israel Journal of Veterinary Medicine, 58(2-3), Retrieved from: http://www. isrvma.org/article/58_2_3.htm

Van Soest, P. J., Robertson, J. B. and Lewis, B. A. 1991. Methods for dietary fibre, neutral detergent fibre and nonstarch polysaccharides in relation to animal nutrition. Journal of Dairy Science, 74: 3583-3597.

Varley, H., Van, E. and Kass I., 1980. Practical clinical chemistry, New York, Inter Science

Publishers Inc., 197-240

Received: 12/01/13 Accepted: 15/09/13 